\title{
Distribution and importance of autotrophic ultraplankton in a boreal inshore area (Kiel Bight, Western Baltic)
}

\author{
Frank Jochem
}

Institut für Meereskunde an der Universität Kiel, Düsternbrooker Weg 20, D-2300 Kiel, Federal Republic of Germany

\begin{abstract}
From April to October 1986, 4 stations in Kiel Bight and Kiel Fjord (Western Baltic) were investigated twice each month for the distribution and importance of autotrophic ultraplankton $(<20 \mu \mathrm{m})$ by size-fractionated records of chlorophyll $a$ and primary productivity within the size classes micro- $>20$ $\mu \mathrm{m})$, nano- ( 3 to $20 \mu \mathrm{m})$ and picoplankton $(<3 \mu \mathrm{m})$ Their development was compared with the physical environment in terms of salinity and temperature profiles and nutrient concentrations. Except the diatomdominated spring bloom and the autumn dinoflagellate bloom, ultraplankton contributed 70 to $100 \%$ of phytoplankton biomass and productivity. The change from 'new' production by microplankton in spring to the ammonia-maintained, mainly 'regenerated' production in summer and again to 'new' production by microplanktonic dinoflagellates in autumn was characterized by a nanoflagellate bloom. In May, this bloom was built up by the non-skeletforming form of the silicoflagellate Dictyocha fibula. In September, Prorocentrum minimum bloomed. In between, nanoplankton was the overall dominating size fraction. Picoplankton attained its greatest importance in mid-summer, contributing 8 to $33 \%$ of total phytoplankton chlorophyll and production. Whereas absolute biomass and productivity of picoplankton, as well as of all other size classes, decreased towards the less eutrophic open Kiel Bight, picoplankton contribution to total phytoplankton biomass and production increased in this direction. Nanoplankton contribution increased towards the eutrophic inner Kiel Fjord. Pycnoclines and nutriclines supported both ultraplankton productivity and the structure of their vertical distribution. If the pycnocline was strong, however, picoplankton seemed unable to pass through it. There were indications of pronounced diurnal vertical migration of the nanoflagellates P. minimum and $D$. fibula.
\end{abstract}

\section{INTRODUCTION}

The existence of very small phytoplanktonic organisms in Kiel Bight has been known of since their discovery by Lohmann $(1908,1911)$. Subsequently, it was however ignored mainly due to technical problems of examination. Nowadays, the great importance of small phytoplankton is well established - and not merely in tropical regions. Even the Antarctic, known as an 'ecosystem of giants', reveals a high contribution of nanoplankton (Bröckel 1981, Probyn \& Painting 1985).

Historically, nanoplankton was defined by different size ranges depending on the mesh sizes available to the different authors. Sieburth et al. (1978) gave a definition of micro- $(>20 \mu \mathrm{m})$ and nanoplankton ( 2 to $20 \mu \mathrm{m})$ and added the term picoplankton for organisms $<2 \mu \mathrm{m}$. To this definition Murphy \& Haugen (1985) added the term ultraplankton, defined as the sum of pico- and nanoplankton, which represents a size range that is often more practicable in field studies.
Although there are numerous reports from oceanic regions, only a few deal with the seasonal distribution of nano- and picoplankton in boreal coastal waters (McCarthy et al. 1974, Durbin et al. 1975, Throndsen 1978, Larsson \& Hagström 1982, Furnas 1983, Joint et al. 1986, Kuparinen 1987). This paper reports the vertical, horizontal and seasonal distributions of nano- and picoplankton chlorophyll and primary productivity and the importance of ultraplankton for the pelagic ecosystem in Kiel Fjord and Kiel Bight throughout the growth season of 1986. Specifically, the effects of pycnoclines and the impact of inorganic nutrient input on phytoplankton size structure are shown, and seasonal changes of phytoplankton size structure are described.

\section{STUDY AREA}

Kiel Bight is enclosed to the west and south but open to influx of higher salinity Kattegat water from the 
northwest and lower salinity water from the Baltic proper from the east. Water in Kiel Bight is mesohaline and the density structure of the water column is salinity- rather than temperature-dependent. Average water depth is $17 \mathrm{~m}$, and the depth of the euphotic zone in Kiel Bight during summer is about $14 \mathrm{~m}$. The plankton of Kiel Bight is typically marine and similar to that characteristic for boreal coastal waters (Smetacek 1981), and the seasonal distribution pattern of larger phytoplankton is well documented. It is characterized by a diatom spring bloom and a dinoflagellate autumn bloom. (For a summary of Kiel Bight plankton ecology see Smetacek et al. 1984.) Total biomass, production, and species composition of micro- and larger nanoplankton have been well-recorded during the numerous investigations in Kiel Bight; but not picoplankton, size fractionation of biomass other than by microscope counting, and fractionated production.

\section{MATERIAL AND METHODS}

The 4 sampling stations lay on a transect through Kiel Fjord and Kiel Bight (Fig. 1) and were chosen to be representative of both the eutrophic fjord and the open bight. Samples were taken on 11 occasions from April to October 1986, once or twice each month. On 12 June and 1 July stations of greater depths $(17$ and $28 \mathrm{~m}$ respectively) in the vicinity of $\operatorname{Stn} D$ were examined instead of the $12 \mathrm{~m}$ standard station.
Temperature and salinity were recorded with a WTW LF $191^{\text {TM }}$. The $1 \%$ light level was calculated from Secchi depth measurements using the formula given by Parsons et al. (1984).

Samples were taken with 5 I black PVC Niskin type water bottles from 3 or 4 depths at each station. At least one of them was situated above, within and beneath the pycnocline. During vertically mixed conditions sampling depths were distributed evenly throughout the euphotic zone. If light penetrated to the bottom with more than $1 \%$ of surface irradiation the deepest sample was taken as close as possible to the bottom.

Silicate, nitrate, nitrite, and ammonia were measured from frozen samples (Grasshoff et al. 1983).

Chlorophyll a concentration and primary productivity were determined in the size classes of micro-, nanoand picoplankton by size fractionation using a $20 \mu \mathrm{m}$ gauze and filtration through $3 \mu \mathrm{m}$ membrane filters under weak pressure $(<200 \mathrm{~mm} \mathrm{Hg})$.

Primary productivity was estimated with the simulated in situ ${ }^{14} \mathrm{C}$-technique (Steemann Nielsen 1952) by incubation for 4 to $6 \mathrm{~h}$ around local noon in a deckincubator exposed to full sunlight and cooled by flowing near-surface seawater. In situ light was simulated by calibrated black and grey nylon gauze placed over the bottles. For the upper and the lower 2 depths the lowest value of one dark bottle and one bottle treated with $10^{-5} \mathrm{~mol} \mathrm{l}^{-1}$ DCMU [3-(3,4-dichlorphenyl)-1,1dimethylurea; Legendre et al. 1983] was used as dark uptake and subtracted from light values. In most cases

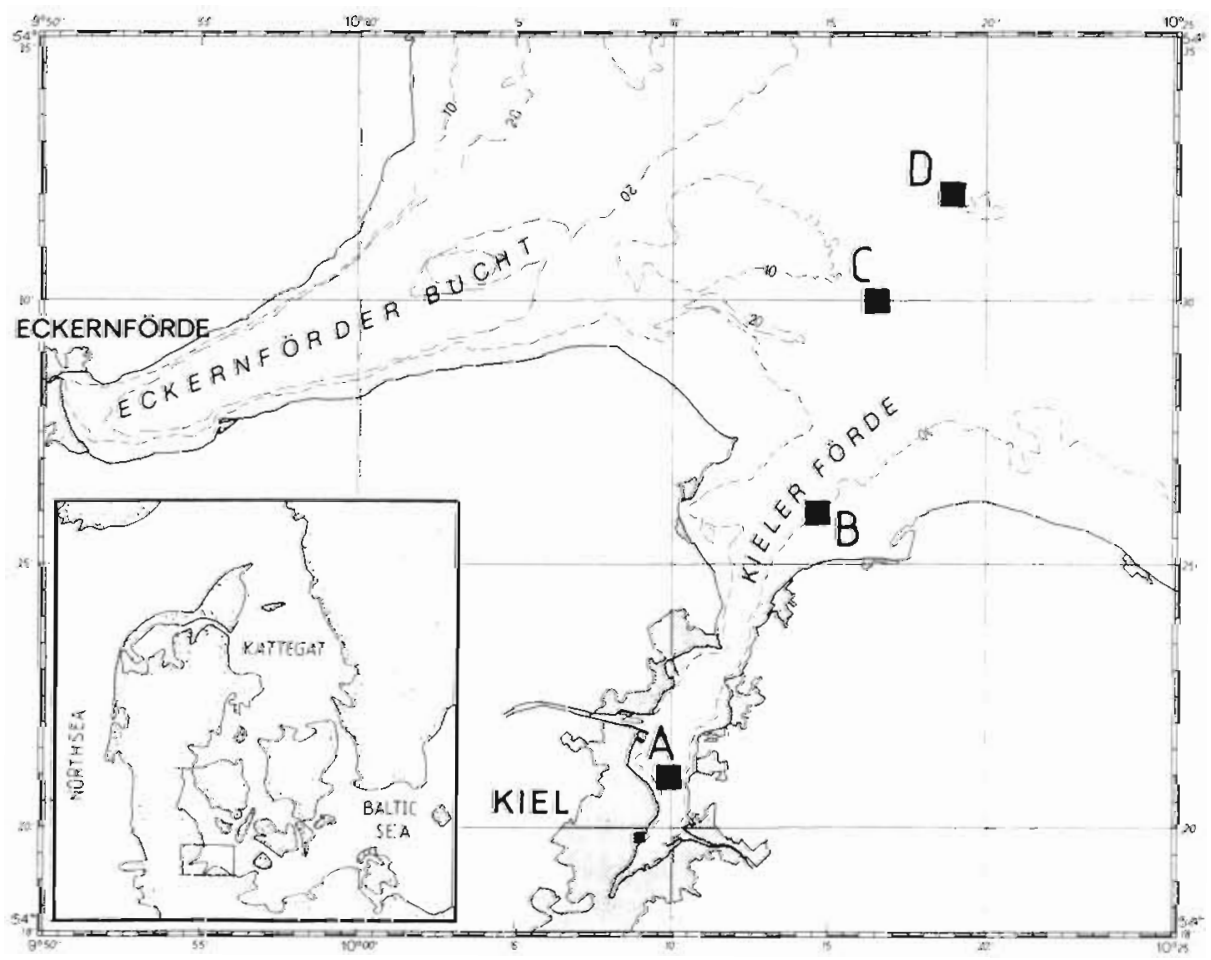

Fig. 1 Location of sampling stations in Kiel Bight and Kiel Fjord 
the DCMU-treated bottles showed lower carbon uptake than normal dark bottles. Incubation was stopped by adding $1.5 \times 10^{-5} \mathrm{~mol} \mathrm{l}^{-1}$ DCMU and the bottle contents subsequently fractionated and filtered. Experiments showed no significant change in the ${ }^{14} \mathrm{C}$ counts within the first $4 \mathrm{~h}$ after adding DCMU. ${ }^{14} \mathrm{C}$-uptake was determined by liquid scintillation measurements.

For fractionation, post-screening was used. This method has the advantage of an undisturbed sample during incubation and yielded higher results than prescreened incubations. For each depth one $250 \mathrm{ml}$ light bottle was incubated; $50 \mathrm{ml}$ aliquots were used for fractionation to avoid variance because of different bottles. Extimates for total productivity were obtained from unfractionated aliquots. After size fractionation by gauze or membrane filters the aliquots were filtered onto Whatman $\mathrm{GF} / \mathrm{F}$. In productivity measurements of a summer sample from Kiel Fjord (August 1985) no significant differences were found between $G F / F$, $0.2 \mu \mathrm{m}$, and $0.45 \mu \mathrm{m}$ membrane filters. This is in agreement with Li et al. (1983) and Herbland et al. (1985).

Chlorophyll was determined with the trichromatic method (Strickland \& Parsons 1972) and concentrations calculated according to Jeffrey \& Humphrey (1975).

\section{RESULTS}

\section{Abiotic determinants}

Vertical salinity and temperature profiles were very similar at all stations, so their seasonal variation is only shown for Stn C (Fig. 2).

Salinity (Fig. 2a) was vertically homogeneous in April $(16 \%)$. Thereafter, it slowly decreased near the surface until mid-September and increased near the bottom. In May and June, a halocline developed at 8 to $10 \mathrm{~m}$ depth, and relatively high surface salinities of 14 to $15 \%$ indicated upwelling of bottom water in inner Kiel Fjord (Stn A). The salinity gradient became weaker during July but strengthened again at the end of August. On 26 August, the halocline centred at $13 \%$ was found at $6 \mathrm{~m}$ depth, whereas in September it centred at $16 \%$ and $12 \mathrm{~m}$ depth. Because of its greater depth in September, it could not be recorded at the shallower stations A and D.

Surface temperatures ranged from 0.7 to $21.6^{\circ} \mathrm{C}$. In the inner fjord they were generally 0.5 to $1 \mathrm{C}^{\circ}$ higher than in the open Kiel Bight. Only in May, June, and early September, they were $1 \mathrm{C}^{\circ}$ lower than in the open bight due to upwelling events in the inner fjord. The vertical structure of temperature (Fig. 2b) was very similar to salinity development. During May and June, a thermocline developed at 8 to $10 \mathrm{~m}$ depth, and a strong heating of the whole water column occurred, the year's highest recorded temperatures being reached on 1 July. During July, the thermocline weakened, and from August to the end of the study temperature was almost homogeneous down to a depth of $12 \mathrm{~m}$, with values in the range 12 to $13^{\circ} \mathrm{C}$ in October.

Due to the diatom spring bloom silicate was depleted at the beginning of this study (Fig. 3). In late May and mid-June, an inflow of silicate-enriched bottom water (>15 $\mathrm{mol} \mathrm{l}^{-1}$ ) occurred. During summer, silicate concentrations ranged from 5 to $15 \mu \mathrm{mol} \mathrm{l}^{-1}$. From early September on, silicate concentrations increased, achieving more than $30 \mu \mathrm{mol} \mathrm{l}^{-1}$ in October.

Whereas silicate was depleted in April, nitrate (Fig. 4) was found in concentrations still $>10 \mu \mathrm{mol} \mathrm{l}^{-1}$, in inner Kiel Fjord (Stn A) $>24 \mu \mathrm{mol} \mathrm{l^{-1 }}$. It became depleted during May. During summer, nitrate was very near or even below the limit of detection, and ammonia (Fig. 5), which averaged about $0.75 \mu \mathrm{mol} \mathrm{l}^{-1}$, with some temporary maxima of up to $8 \mu \mathrm{mol} \mathrm{l}^{-1}$, became the main nitrogen source for primary production. From late September on, nitrate concentrations recovered by 1 to $2 \mu \mathrm{mol} \mathrm{l}{ }^{-1}$. Nitrite ranged from about 0.2 to $0.3 \mu \mathrm{mol} \mathrm{l}^{-1}$, never attaining major importance as a nitrogen source
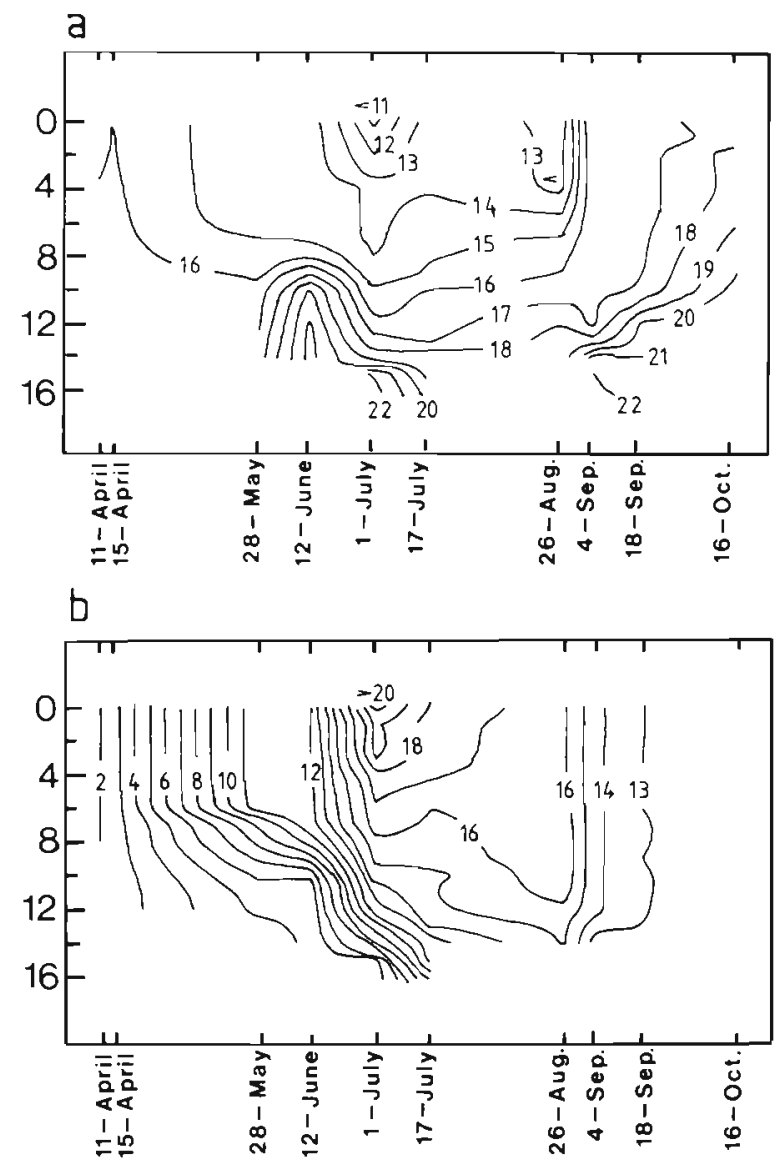

Fig. 2. Seasonal distribution of (a) salinity [\%o] and (b) temperature $\left[{ }^{\circ} \mathrm{C}\right]$ at $\operatorname{Stn} \mathrm{C}$. Depths in $\mathrm{m}$ 

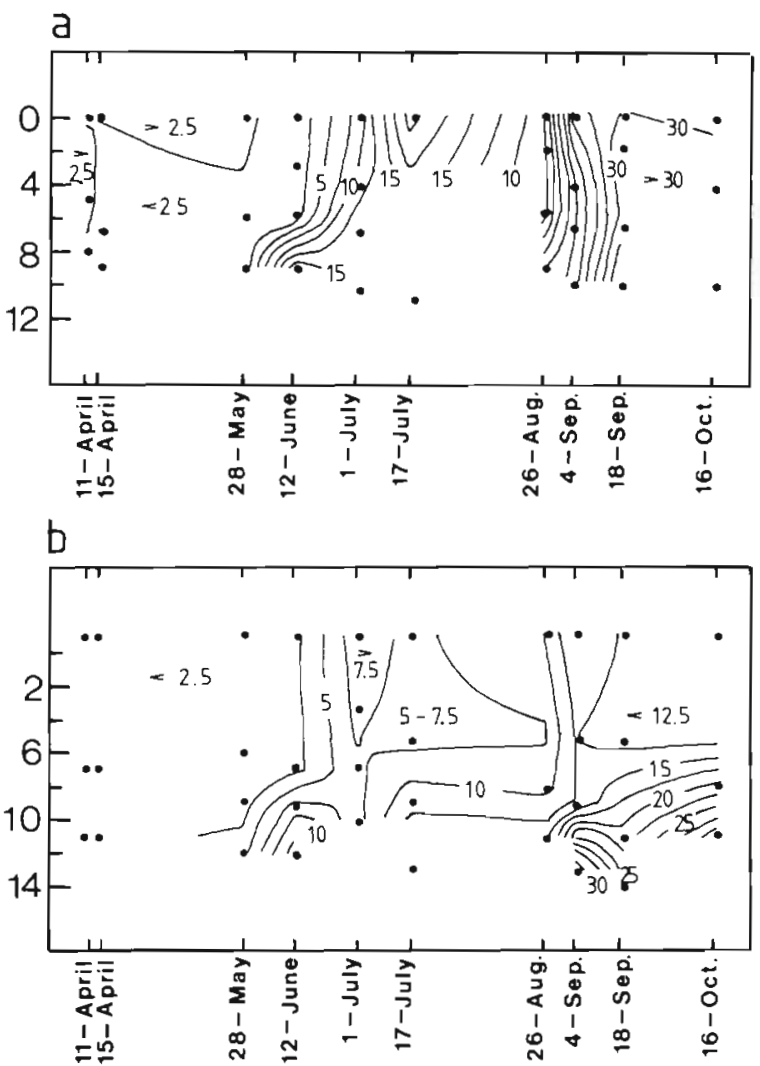

Fig. 3. Seasonal distribution of silicate $\left[\mu \mathrm{mol} \mathrm{l}^{-1}\right]$ at (a) Stn $A$, (b) Stn C. Depths in m

for phytoplankton growth. In early September, it peaked up to $1.2 \mu \mathrm{mol} 1^{-1}$, presumably because of oxygen depletion in bottom water in Kiel Bight. As ammonia had reached up to $6 . \mathrm{mol}^{-1}$ at this time and levels of nitrate had recovered, nitrite might still have played a minor role in phytoplankton nutrition.

\section{Chlorophyll}

Despite the higher concentrations in inner Kiel Fjord (Stn A) and some differences in vertical distribution the general development of total chlorophyll was quite similar among stations except for Stn D (Fig. 6). Maximum chlorophyll concentrations were about $77 \mu \mathrm{g} \mathrm{l^{-1 }}$ at $\operatorname{Stn} \mathrm{A}$, and about 15 to $20 \mu \mathrm{g} \mathrm{l}^{-1}$ at the other stations. In April, chlorophyll concentrations were up to $20 \mathrm{\mu g} \mathrm{l}^{-1}$ at Stns $A$ and $D$, presumably due to the diatom spring bloom. All stations were characterized by a high biomass in May $\left(\leq 25 \mu \mathrm{g} \mathrm{l}^{-1}\right.$ at Stn $A_{1} \leq 10$ to $14 \mu \mathrm{gl}^{-1}$ at the others). The depth of the population maximum increased from $6 \mathrm{~m}$ at $\mathrm{Stn} A$ to more than $10 \mathrm{~m}$ at $\operatorname{Stns} C$ and $D$. Microscopic examination revealed that this population was built up by the non-skeletforming form of the silicoflagellate Dictyocha fibula (syn. Dis-
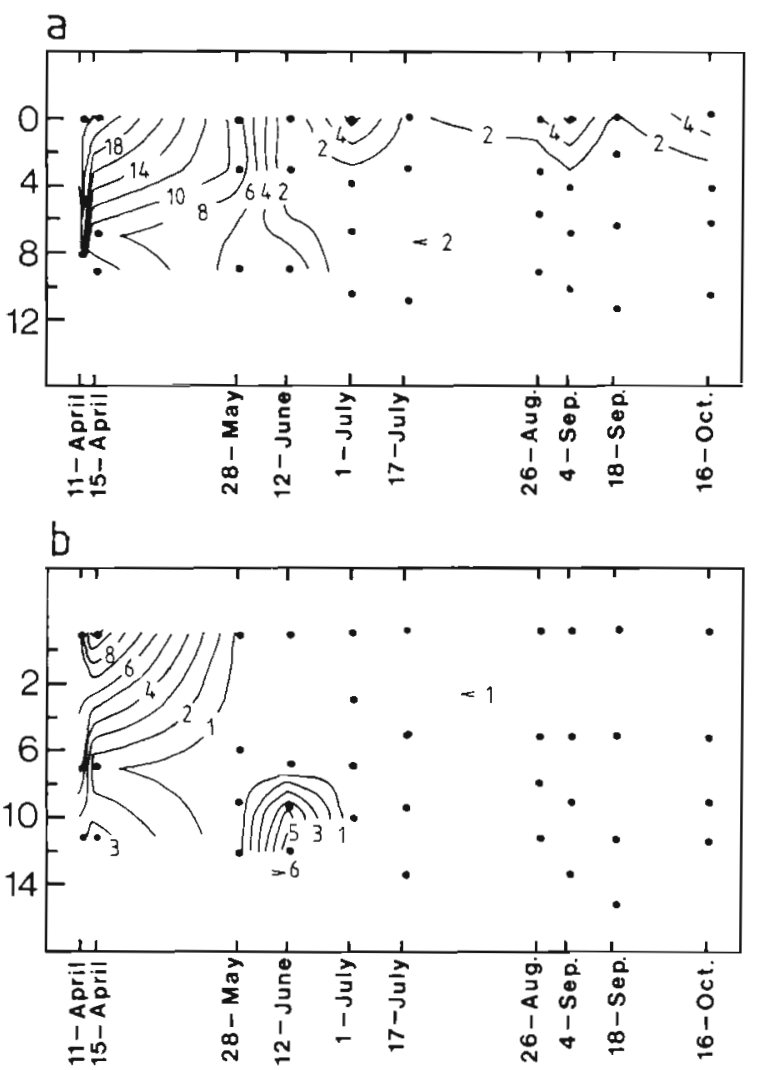

Fig. 4. Seasonal distribution of nitrate $\left[\mathrm{umol} \mathrm{l}^{-1}\right]$ at (a) Stn $A$, (b) Stn C. Depths in m

tephanus speculum; Valkenburg \& Morris 1970). In June, a weak bloom of Skeletonema costatum occurred at Stns $\mathrm{A}$ and $\mathrm{B}$. Thereafter, chl a concentrations were about 5 to $10 \mu \mathrm{g} \mathrm{l}^{-1}$ at the fjord stations $(A, B)$ and 2 to $4 \mu \mathrm{g} 1^{-1}$ at the Bight stations (C, D). Slightly higher values were found in medium depths in August, caused by the dinoflagellate Prorocentrum minimum, except for Stn D. This species remained growing until the end of October and caused increasing chl a values at all stations. In the inner fjord it formed a 'red tide'.

Microplankton chlorophyll concentrations decreased during April and May and remained very low 10 to $2 \mu \mathrm{g}$ $1^{-1}$ ) until early September, thus being of minor importance during summer. At Stn $\mathrm{A}$, the short blooming of Skeletonema costatum caused somewhat higher microplankton chlorophyll values of up to $8 \mu \mathrm{gl}^{-1}$ in June. In September and October, an increase of microplankton biomass was observed, and in October it recovered to values $>4 \mu^{-1}$, contributing 60 to $90 \%$ of total chlorophyll except at Stn A.

The development of nanoplankton chlorophyll essentially paralleled total chlorophyll except for the October biomass increase at the open Bight stations. From May to September it accounted for 40 to $90 \%$ of total chlorophyll and was the overall dominating size 

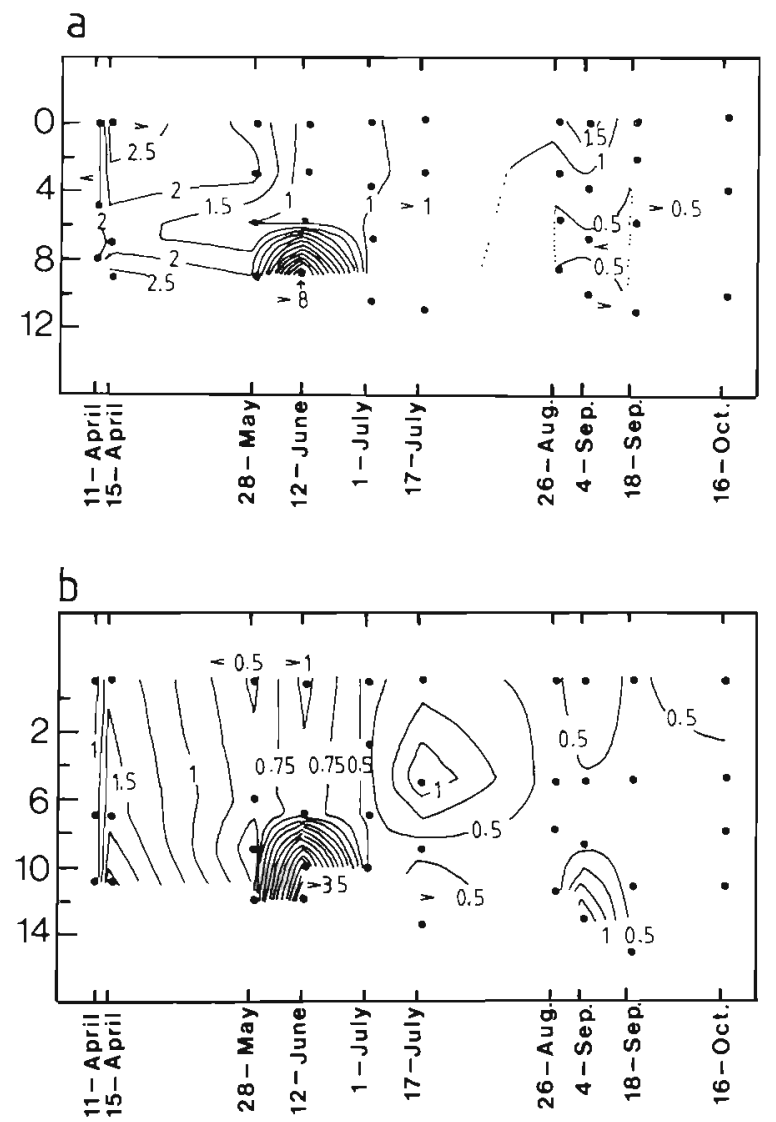

Fig. 5. Seasonal distribution of ammonia $\left.[\mu \mathrm{mol}]^{-1}\right]$ at (a) $\operatorname{Stn} A$, (b) Stn C. Depths in $m$

fraction. Microscopic examination confirmed that the blooms in May and September/October were almost entirely contributed by the nanoflagellates Dictyocha fibula and Prorocentrum minimum respectively.

Picoplankton showed a distinct chlorophyll maximum in May at the site of total and nanoplankton chlorophyll maximum; it accounted for $\leq 54 \%$ of total chlorophyll. The disintegration of the very fragile nonskeletforming Dictyocha fibula during size fractionation by 3 m membrane filters under weak pressure has to be considered as part of the origin of this 'picoplankton population: In July, a picoplankton chlorophyll maximum was found near the bottom, at Stn $\mathrm{A}$ also at the surface, that contributed more than $1 \mu \mathrm{g} \mathrm{l^{-1 }}$ and accounted for 24 to $57 \%$ of total chlorophyll. During summer, picoplankton chlorophyll ranged from 0.4 to $0.6 \mu \mathrm{gl}^{-1}$, at Stn A up to $0.8 \mu \mathrm{gl}^{-1}$, and contributed 8 to $19 \%$ of total chlorophyll. In early September, picoplankton chlorophyll values were elevated at the 3 inner stations, the $0.8 \mu \mathrm{g} l^{-1}$ isoline deepening from $2 \mathrm{~m}$ at Stn A to $11 \mathrm{~m}$ at Stn C. At Stn D, higher concentrations (>0.8 $\mu \mathrm{g} \mathrm{l}^{-1}$ ) near the bottom were observed at this time. Because of the simultaneous increase of Prorocentrum minimum in Kiel Fjord, picoplankton con- tribution to total chlorophyll was higher (24 to $28 \%$ ) only at the Bight stations $\mathrm{C}$ and $\mathrm{D}$ at this time. Thereafter, picoplankton biomass decreased to below 0.4 $\mu \mathrm{g} \mathrm{l}^{-1}$, its contribution to less than 5 to $8 \%$, and at Stn $\mathrm{A}$ even less than $2 \%$.

Chlorophyll concentrations integrated over the euphotic zone are depicted cumulatively for each station and size fraction in Fig. 7 and data are given in Table 1 .

Integrated chlorophyll concentrations reveal the same seasonal development of phytoplankton biomass and size distribution as described above. Concentrations in inner Kiel Fjord (Stn A) generally were 3 times higher than at the other stations. Microplankton had a high contribution only at the beginning and the end of the study period and nanoplankton was the dominating size fraction in terms of chlorophyll biomass. Picoplankton had its highest contribution on 1 July (20 to $39 \%$ ) and at the end of August/beginning of September ( 8 to $25 \%$ ). This coincided with the 2 population maxima of picocyanobacteria which contributed about $76 \%$ and $96 \%$ to autotrophic picoplankton on $1 \mathrm{July}$ and 26 August, respectively (Jochem 1987, 1988).

\section{Primary productivity}

Total primary productivity decreased towards the open bight (Fig. 8). In the inner Kiel Fjord it was always higher by a factor of about 5 than at the other stations. The high biomass at medium depths in May was not reflected by higher productivity. In June, the Skeletonema costatum bloom caused a productivity maximum in Kiel Fjord (Stn A: $\leq 116 \mu \mathrm{g} \mathrm{C} l^{-1} \mathrm{~h}^{-1}$; Stn $\mathrm{B}: \leq 28 \mu \mathrm{g} \mathrm{Cl}^{-1} \mathrm{~h}^{-1}$ ). At depths below 8 to $11 \mathrm{~m}$ productivity decreased rapidly because of light limitation. At

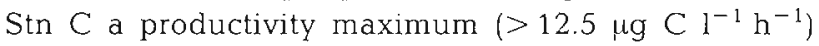
occurred at greater depths in July; a similar maximum was found at the surface of Stn D in late August. During September and October, primary productivity generally increased and highest values were observed at greater depths at Stn A, medium depths at Stns B and $C$ and at the surface at Stn D.

Microplankton productivity decreased rapidly during April and May. With the exception of the already mentioned bloom of Skeletonema costatum in Kiel Fjord in June, it was very low during summer $(\leq 2 \mu \mathrm{g} \mathrm{C}$ $1^{-1} \mathrm{~h}^{-1}$ ) and accounted for only 5 to $10 \%$ of total productivity. From September on, it recovered and contributed 60 to $80 \%$ of total primary production at the end of the study. At Stn A, however, this increase of microplankton productivity was only weak.

During April and May, nanoplankton productivity increased in Kiel Fjord (Stns A and B), remained constant at Stn $C$ and decreased at Stn D. This reflected the 
STATION A
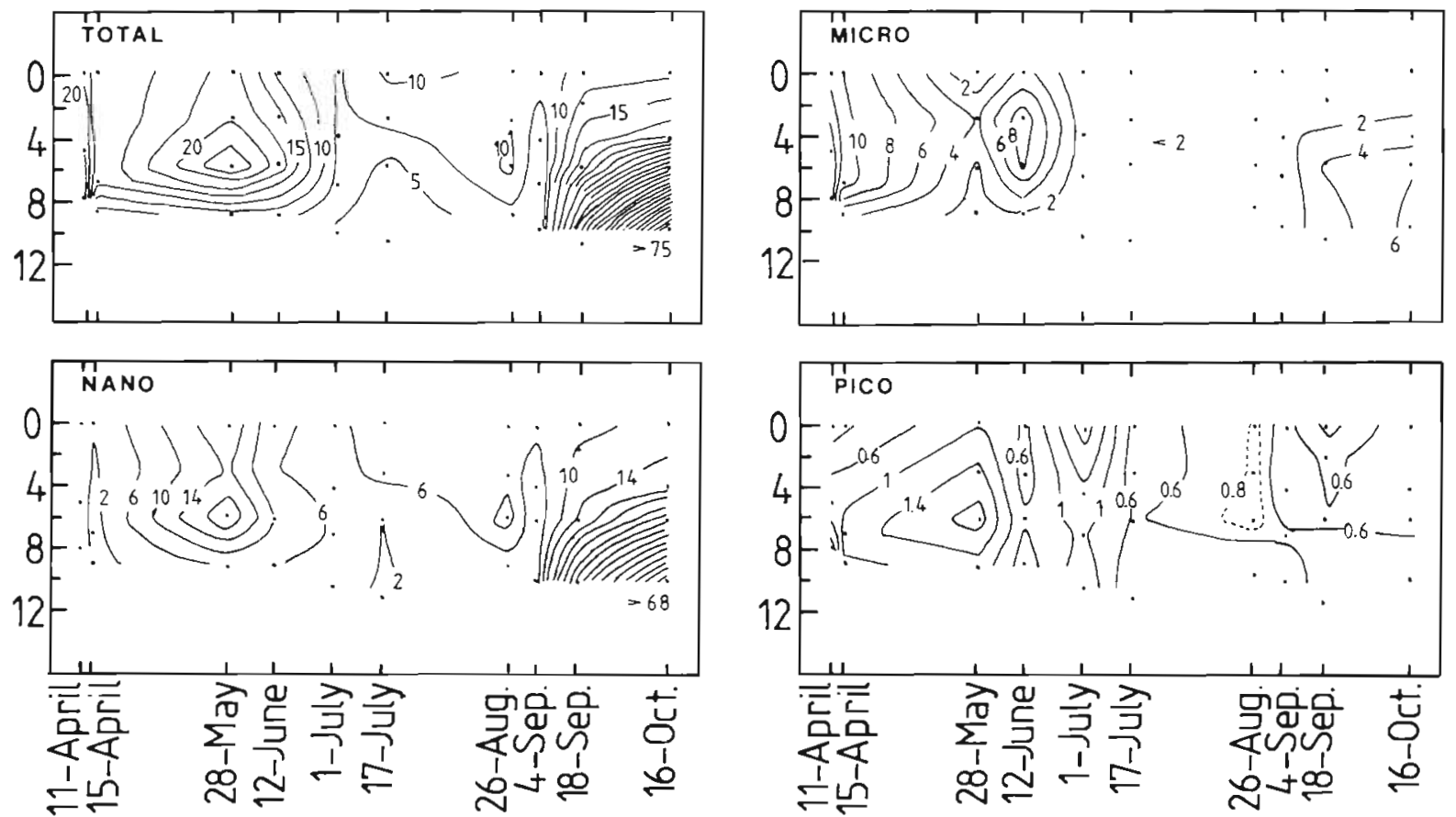

\section{STATION B}
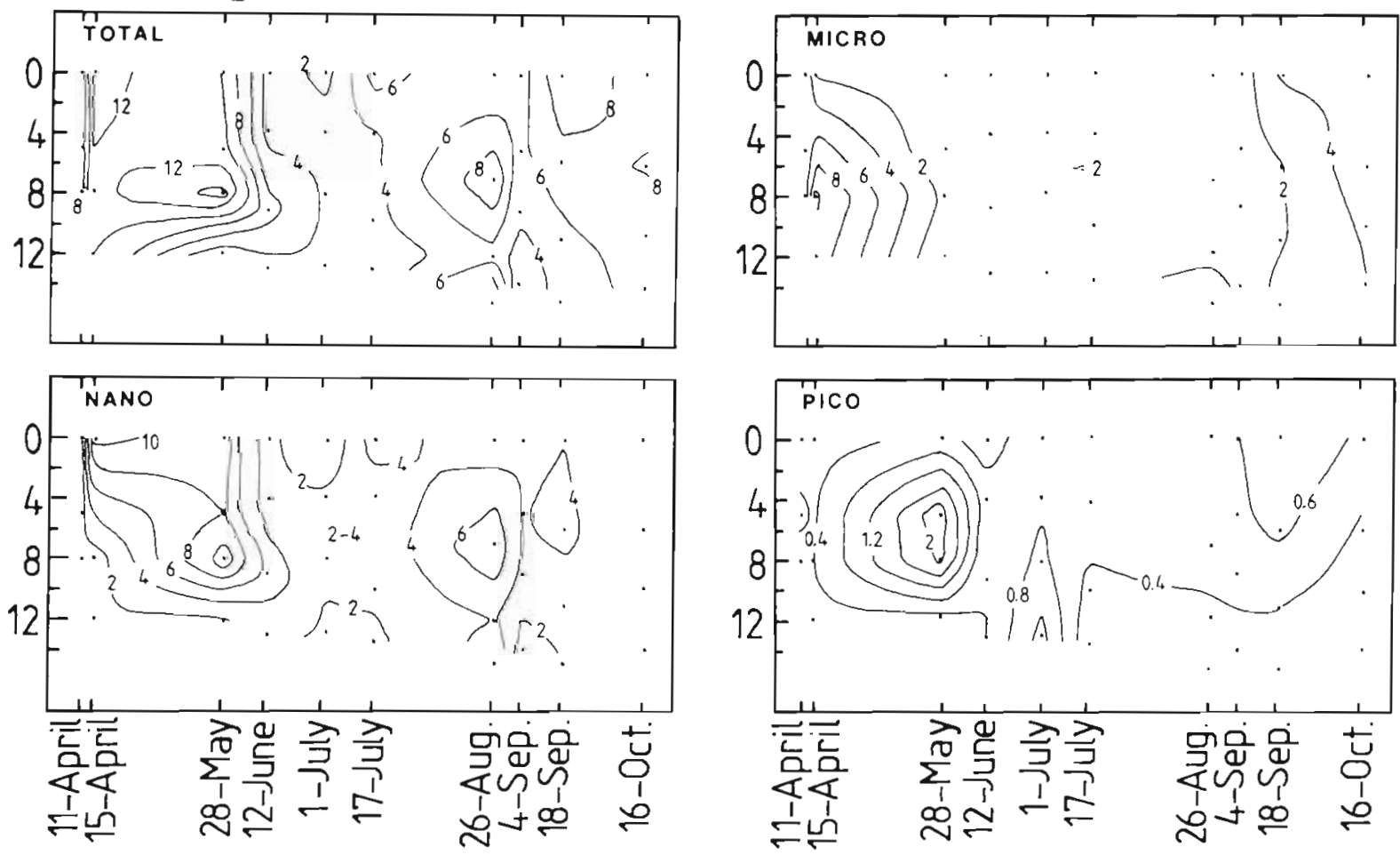

Fig. 6. Seasonal distribution of chlorophyll a $\left[\mu \mathrm{g}^{-1}\right]$ of total phytoplankton and each size fraction at the 4 stations. Depths in $\mathrm{m}$ 


\section{STATION C}
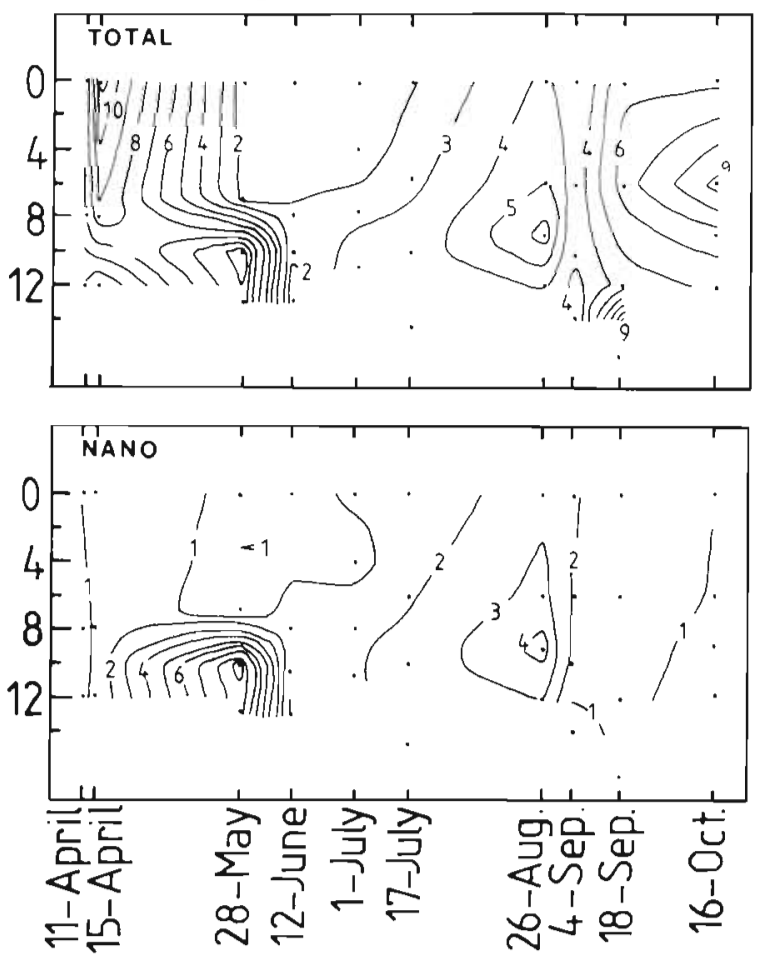
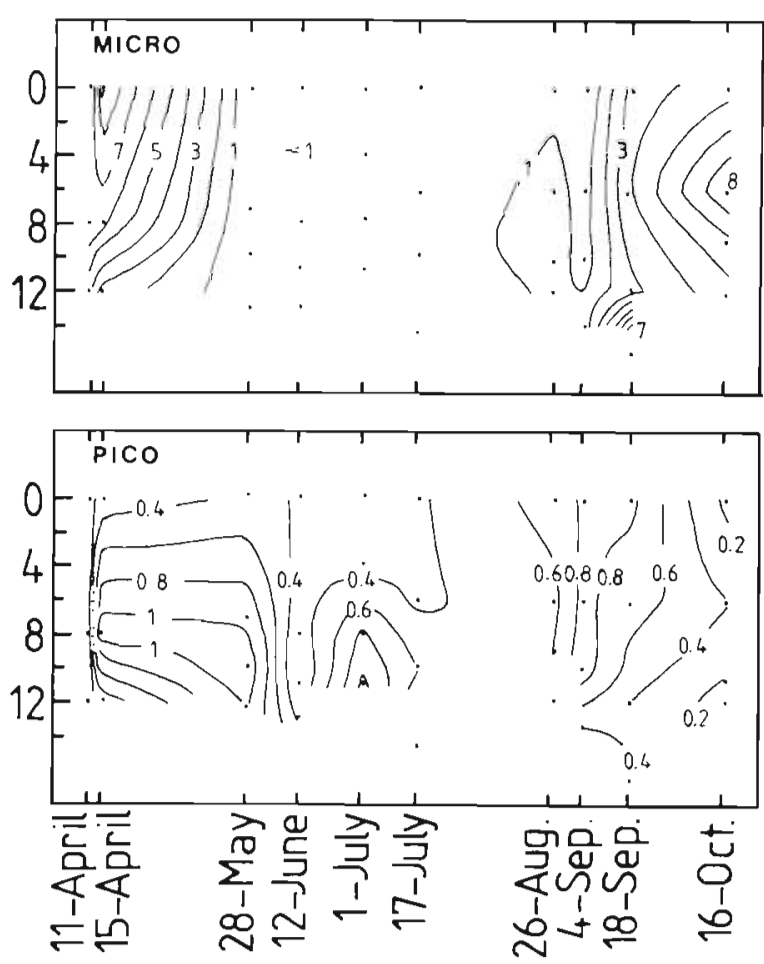
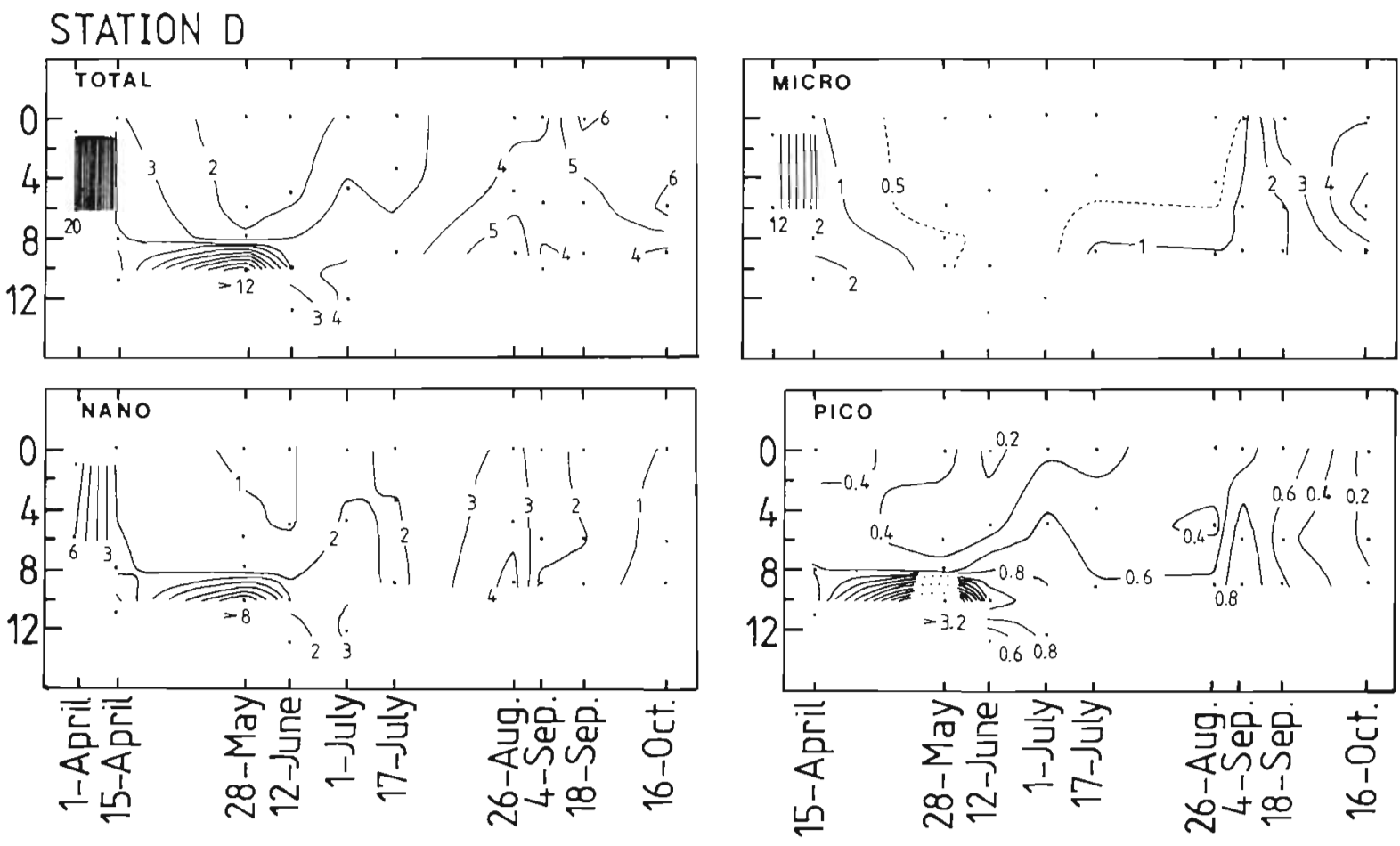

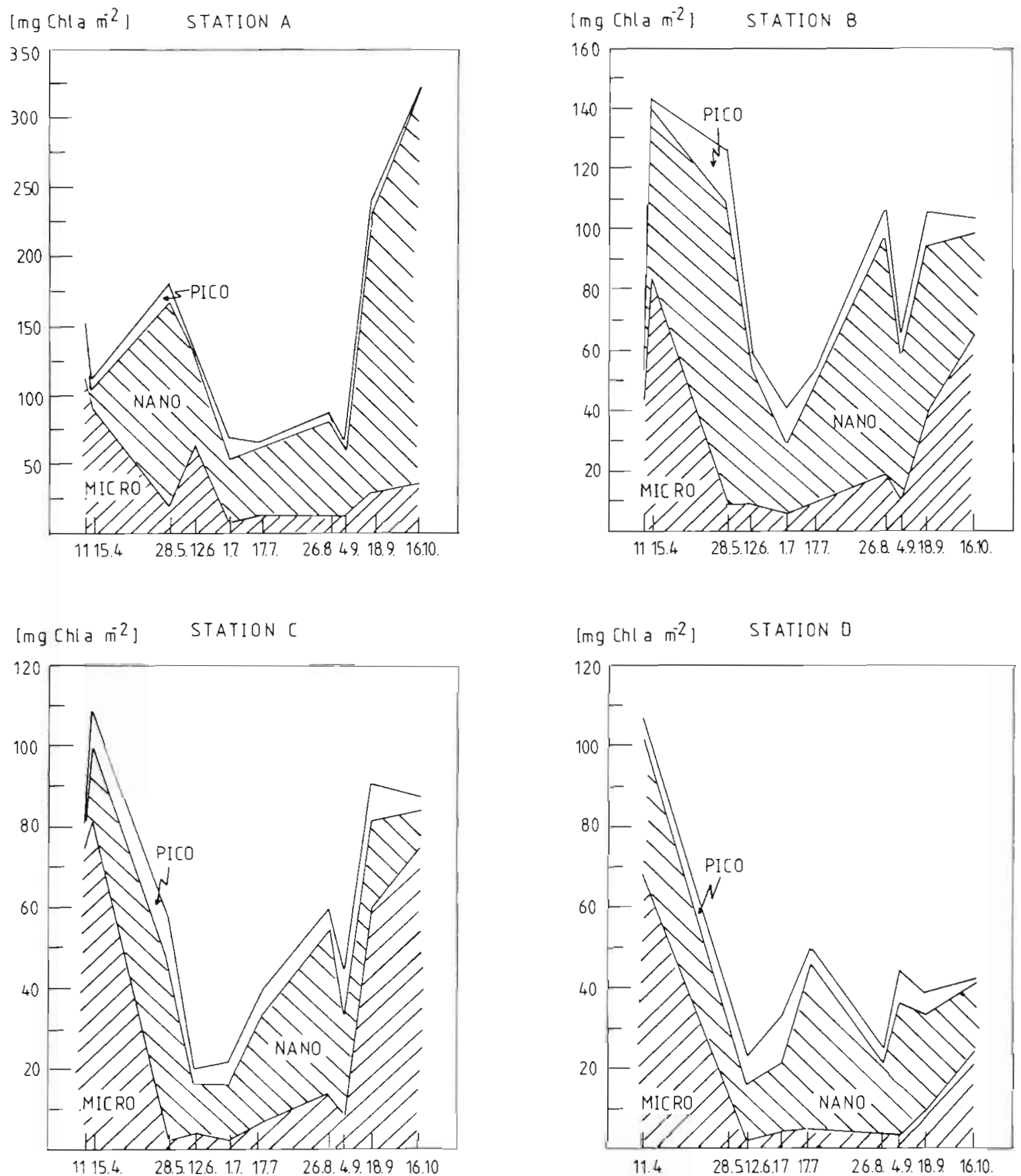

Fig. 7. Chlorophyll concentrations integrated over the euphotic zone $\left[\mathrm{mg} \mathrm{m}^{-2}\right]$ at the 4 stations. Note different scales for each station

amount of nanoplankton chlorophyll that could already be found at the beginning of this study, Like total productivity, the high nanoplankton biomass in May was not reflected by nanoplankton productivity. From June to September, nanoplankton productivity paralleled the figures for total productivity. Contributing 70 to $100 \%$ of primary production during summer, nanoplankton was the overall dominating size fraction in primary productivity, too. Whereas nanoplankton productivity decreased during September and October at the other stations (down to $<20$ to $30 \%$ ), it still increased in the inner fjord (Stn A) with a maximum near the bottom, due to the bloom of Prorocentrum minimum.

Picoplankton productivity decreased during April and May, except for Stn B where it showed higher values at the site of the chlorophyll maximum of the 
Table 1. Depth-integrated values of chlorophyll and primary production and the contribution of each size fraction. Integrated over the euphotic zone

\begin{tabular}{|c|c|c|c|c|c|c|c|c|}
\hline \multirow[t]{2}{*}{ Date } & \multicolumn{4}{|c|}{ Chlorophyll ( $\mathrm{mg} \mathrm{m}^{-2}$ ) } & \multicolumn{4}{|c|}{ Primary production $\left(\mu \mathrm{g} \mathrm{m}^{-2} \mathrm{~h}^{-1}\right)$} \\
\hline & Total & $\%$ Micro & $\%$ Nano & $\%$ Pico & Total & $\%$ Micro & $\%$ Nano & $\%$ Pico \\
\hline \multicolumn{9}{|c|}{ Station A } \\
\hline $11 \mathrm{Apr}$ & 351.4 & 80.6 & 11.9 & 7.5 & 153.3 & 73.4 & 24.0 & 2.6 \\
\hline $15 \mathrm{Apr}$ & & & & & 111.3 & 82.9 & 10.9 & 6.2 \\
\hline 28 May & 353.9 & 11.2 & 85.6 & 3.2 & 181.4 & 10.6 & 81.9 & 7.5 \\
\hline 12 Jun & 912.6 & 48.9 & 50.6 & 0.5 & 137.4 & 46.8 & 49.6 & 3.4 \\
\hline $01 \mathrm{Jul}$ & 468.5 & 3.5 & 92.0 & 4.4 & 68.4 & 9.8 & 69.5 & 20.8 \\
\hline $17 \mathrm{Jul}$ & 356.0 & 6.3 & 91.2 & 2.5 & 66.4 & 19.3 & 73.5 & 7.2 \\
\hline $26 \mathrm{Aug}$ & 168.0 & 3.2 & 85.3 & 11.5 & 87.3 & 14.1 & 77.6 & 8.3 \\
\hline 04 Sep & 230.4 & 7.5 & 80.1 & 12.4 & 64.8 & 18.4 & 75.1 & 6.5 \\
\hline $18 \mathrm{Sep}$ & 639.0 & 2.2 & 92.4 & 5.4 & 238.8 & 11.7 & 83.7 & 3.4 \\
\hline $16 \mathrm{Oct}$ & 687.2 & 4.1 & 92.9 & 3.0 & 321.0 & 11.2 & 87.5 & 1.3 \\
\hline \multicolumn{9}{|c|}{ Station B } \\
\hline 11 Apr & 91.1 & 77.7 & 9.9 & 12.4 & 55.1 & 78.0 & 17.7 & 4.3 \\
\hline $15 \mathrm{Apr}$ & & & & & 141.9 & 59.1 & 39.3 & 2.6 \\
\hline $28 \mathrm{May}$ & 104.4 & 17.8 & 60.2 & 22.1 & 125.9 & 6.7 & 78.9 & 14.4 \\
\hline 12 Jun & 286.4 & 21.4 & 77.2 & 1.4 & 59.2 & 15.4 & 74.7 & 9.9 \\
\hline $01 \mathrm{Jul}$ & 176.0 & 11.5 & 80.5 & 8.0 & 40.3 & 13.1 & 58.5 & 28.6 \\
\hline $17 \mathrm{Jul}$ & 31.1 & 0.0 & 100.0 & 0.0 & 53.4 & 17.5 & 72.3 & 10.3 \\
\hline $26 \mathrm{Aug}$ & 170.8 & 11.4 & 76.2 & 12.4 & 105.8 & 17.8 & 74.5 & 7.8 \\
\hline 04 Sep & 214.6 & 7.4 & 78.5 & 14.1 & 65.6 & 15.9 & 71.4 & 12.6 \\
\hline $18 \mathrm{Sep}$ & 301.5 & 34.1 & 56.2 & 9.7 & 105.5 & 36.9 & 52.3 & 10.8 \\
\hline $16 \mathrm{Oct}$ & 250.5 & 61.1 & 30.1 & 8.8 & 103.3 & 62.5 & 32.3 & 5.2 \\
\hline \multicolumn{9}{|c|}{ Station C } \\
\hline $11 \mathrm{Apr}$ & 102.2 & 84.3 & 1.7 & 14.0 & 81.2 & 92.4 & 7.7 & 0.0 \\
\hline $15 \mathrm{Apr}$ & & & & & 108.9 & 75.3 & 17.0 & 7.8 \\
\hline 28 May & 29.1 & 9.2 & 66.6 & 24.1 & 55.5 & 4.3 & 76.3 & 19.8 \\
\hline 12 Jun & 78.8 & 17.5 & 72.4 & 10.1 & 19.9 & 20.5 & 61.1 & 18.6 \\
\hline $01 \mathrm{Jul}$ & 76.0 & 15.7 & 76.2 & 8.0 & 22.2 & 10.5 & 61.4 & 28.0 \\
\hline $17 \mathrm{Jul}$ & 77.2 & 26.8 & 66.6 & 6.5 & 37.5 & 16.6 & 67.4 & 16.0 \\
\hline $26 \mathrm{Aug}$ & 94.2 & 13.4 & 68.1 & 18.5 & 61.0 & 22.6 & 66.7 & 8.8 \\
\hline 04 Sep & 125.2 & 21.4 & 58.4 & 20.3 & 44.2 & 19.6 & 55.0 & 25.5 \\
\hline $18 \mathrm{Sep}$ & 189.1 & 48.7 & 40.2 & 11.1 & 90.8 & 64.7 & 24.9 & 10.4 \\
\hline $16 \mathrm{Oct}$ & 168.4 & 71.2 & 22.5 & 6.3 & 87.5 & 84.7 & 11.4 & 3.9 \\
\hline \multicolumn{9}{|c|}{ Station D } \\
\hline $11 \mathrm{Apr}$ & 150.9 & 76.5 & 20.7 & 0.0 & & & & \\
\hline $15 \mathrm{Apr}$ & & & & & 101.3 & 67.3 & 32.7 & 5.2 \\
\hline 28 May & 15.6 & 11.7 & 64.9 & 23.4 & 40.4 & 38.3 & 48.8 & 13.4 \\
\hline 12 Jun & 61.2 & 20.8 & 77.5 & 1.7 & 21.2 & 7.0 & 67.4 & 32.0 \\
\hline $01 \mathrm{Jul}$ & 154.6 & 27.5 & 65.2 & 7.3 & 28.7 & 15.0 & 61.3 & 38.8 \\
\hline $17 \mathrm{Jul}$ & 92.8 & 17.5 & 70.9 & 11.6 & 56.6 & 8.9 & 71.3 & 7.4 \\
\hline $26 \mathrm{Aug}$ & 68.3 & 16.1 & 73.6 & 10.3 & 25.1 & 12.5 & 70.9 & 17.0 \\
\hline $04 \mathrm{Sep}$ & 97.8 & 21.4 & 58.7 & 19.9 & 40.3 & 7.8 & 81.7 & 20.3 \\
\hline $18 \mathrm{Sep}$ & 77.7 & 35.9 & 51.6 & 12.5 & 41.4 & 22.3 & 58.0 & 13.0 \\
\hline $16 \mathrm{Oct}$ & 88.7 & 68.4 & 15.7 & 15.8 & 46.0 & 52.2 & 36.2 & 2.9 \\
\hline
\end{tabular}

Dictyocha fibula bloom. Here, too, disintegration of $D$. fibula during size fractionation by $3 \mu \mathrm{m}$ filters has to be considered. At Stn D, nano- and picoplankton productivity could not be separated in April. Picoplankton

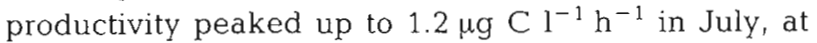
Stn A up to more than $3 \mu \mathrm{g} \mathrm{C}^{-1} \mathrm{~h}^{-1}$, and contributed up to between 10 and $12 \%$ of total productivity. During summer, picoplankton produced 0.4 to $1.0 \mu \mathrm{g} \mathrm{Cl}^{-1} \mathrm{~h}^{-1}$, at $\operatorname{Stn} \mathrm{A}$ it produced 1 to $3 \mu \mathrm{g} \mathrm{Cl} \mathrm{l}^{-1} \mathrm{~h}^{-1}$. It accounted for 4 to $16 \%$ of total primary production with its contribution increasing towards the open Kiel Bight. In late
August and early September, picoplankton productiv-

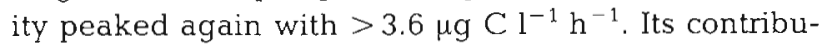
tion attained up to $12 \%$ at $\mathrm{Stn} \mathrm{A}$ and up to $32 \%$ at Stn $C$; again, the contribution was higher in Kiel Bight than in Kiel Fjord. Thereafter, picoplankton productivity decreased and accounted for less than 4 to $8 \%$ of total productivity. Only Stn D showed an increase to $2.5 \mu \mathrm{g}$ $\mathrm{C}^{-1} \mathrm{~h}^{-1}$ and $>20 \%$ of total primary production.

Integrated primary production is depicted cumulatively in Fig. 9 for each size fraction and station and data are given in Table 1 . 
STATION A
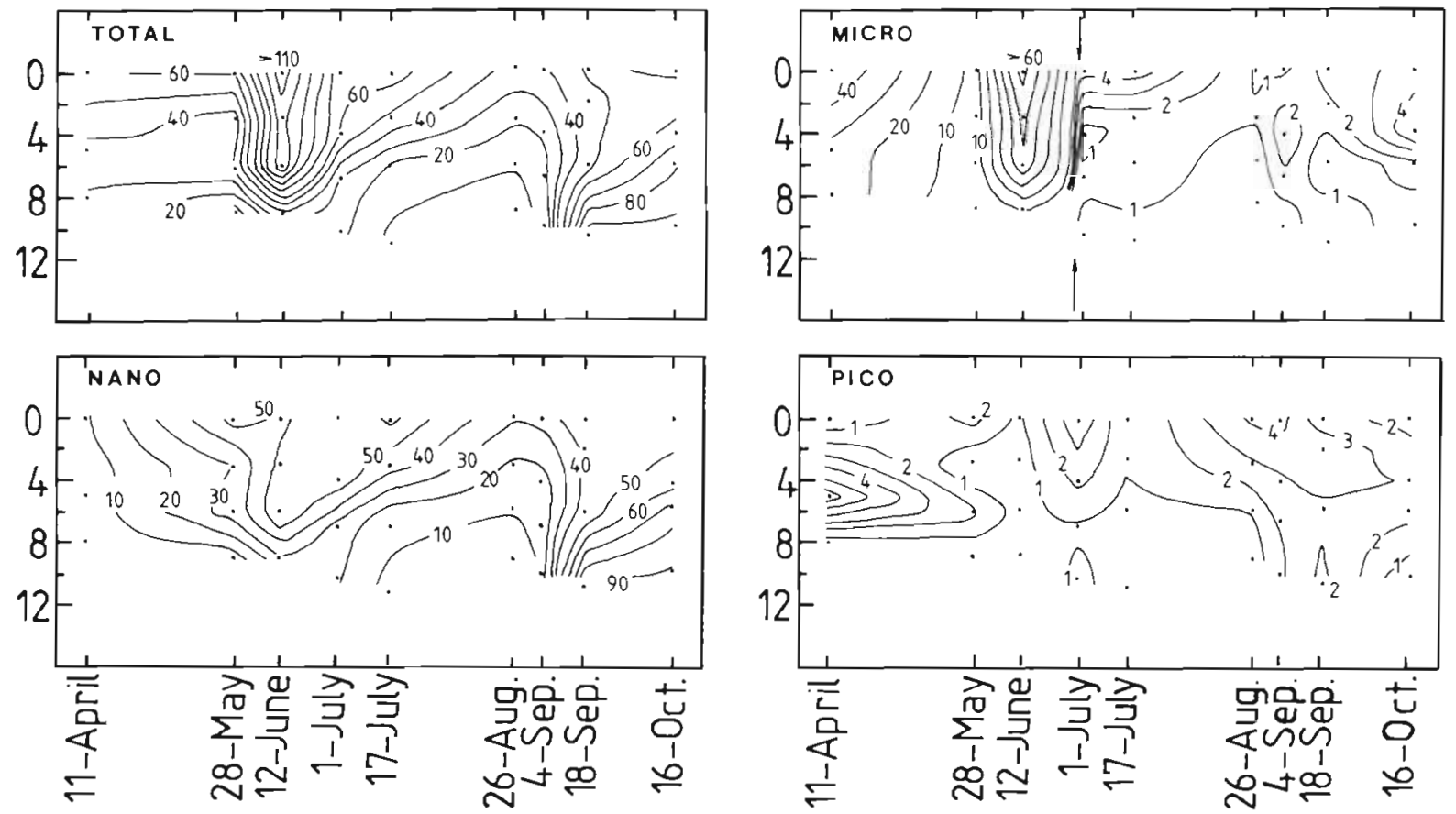

\section{STATION B}
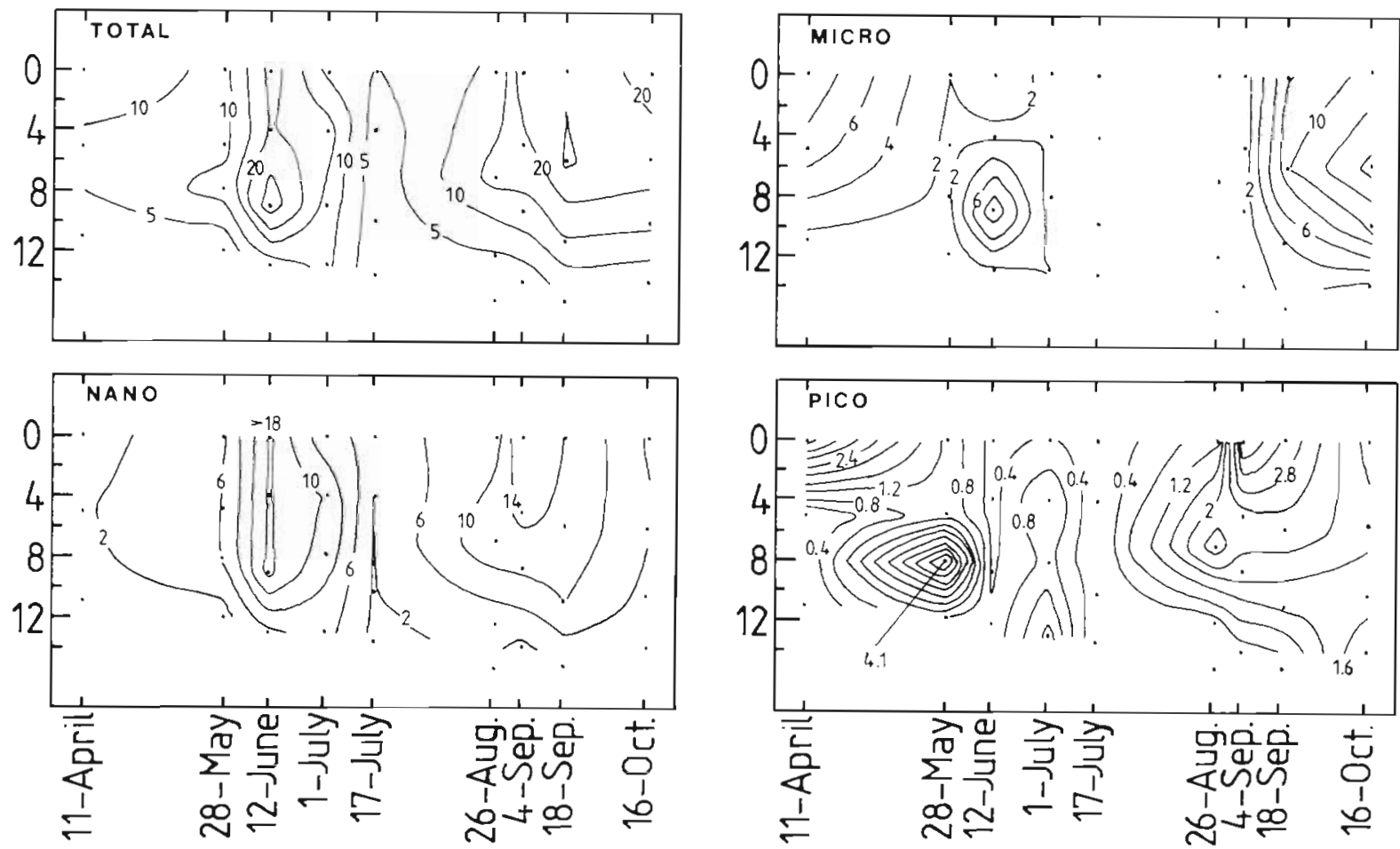

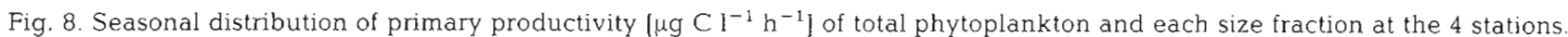
Note different isoplethe scale after 1 July in figure for Stn A, Micro, and from 28 May in Stn D, Micro (indicated by arrows). Depths 

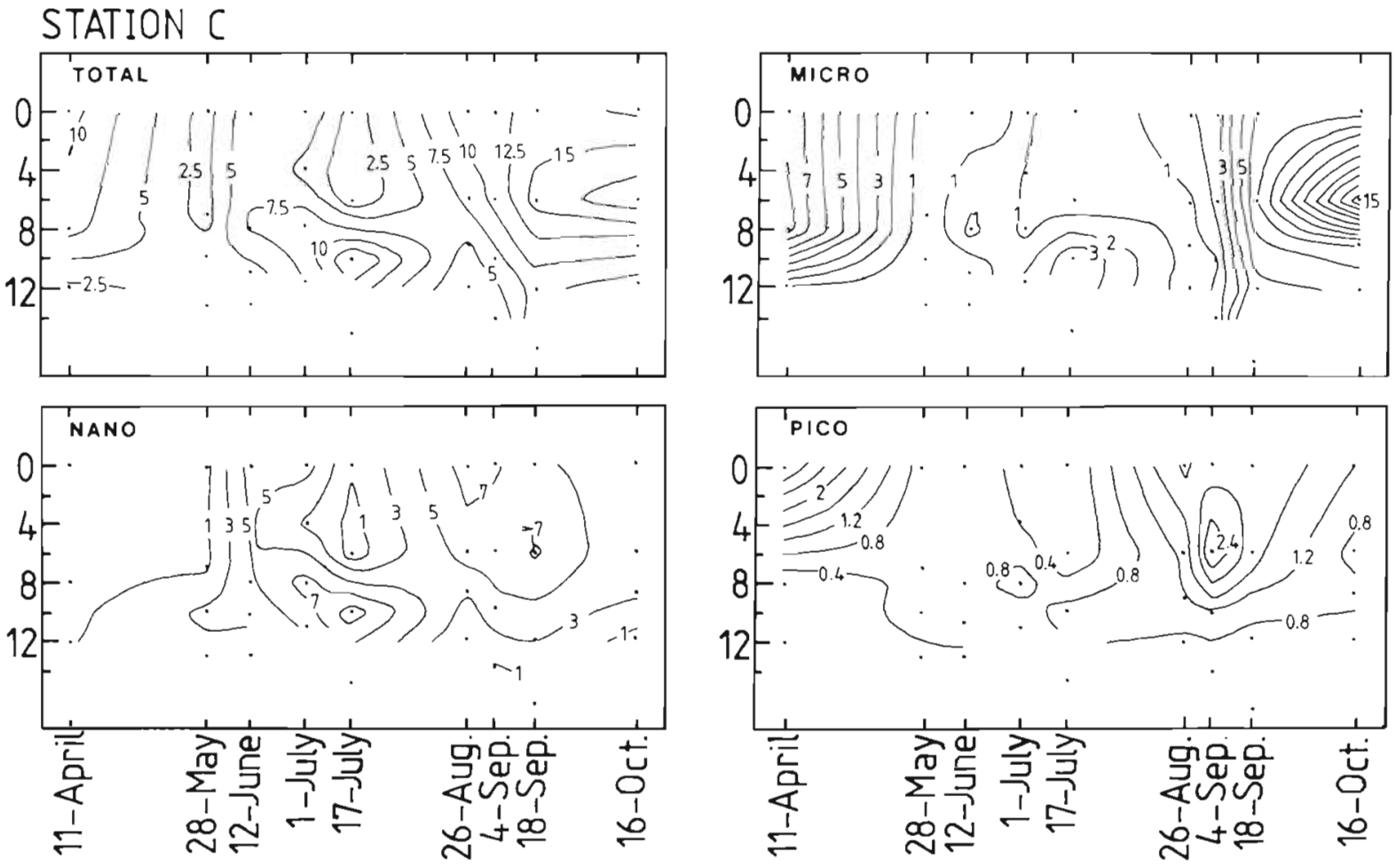

STATION D
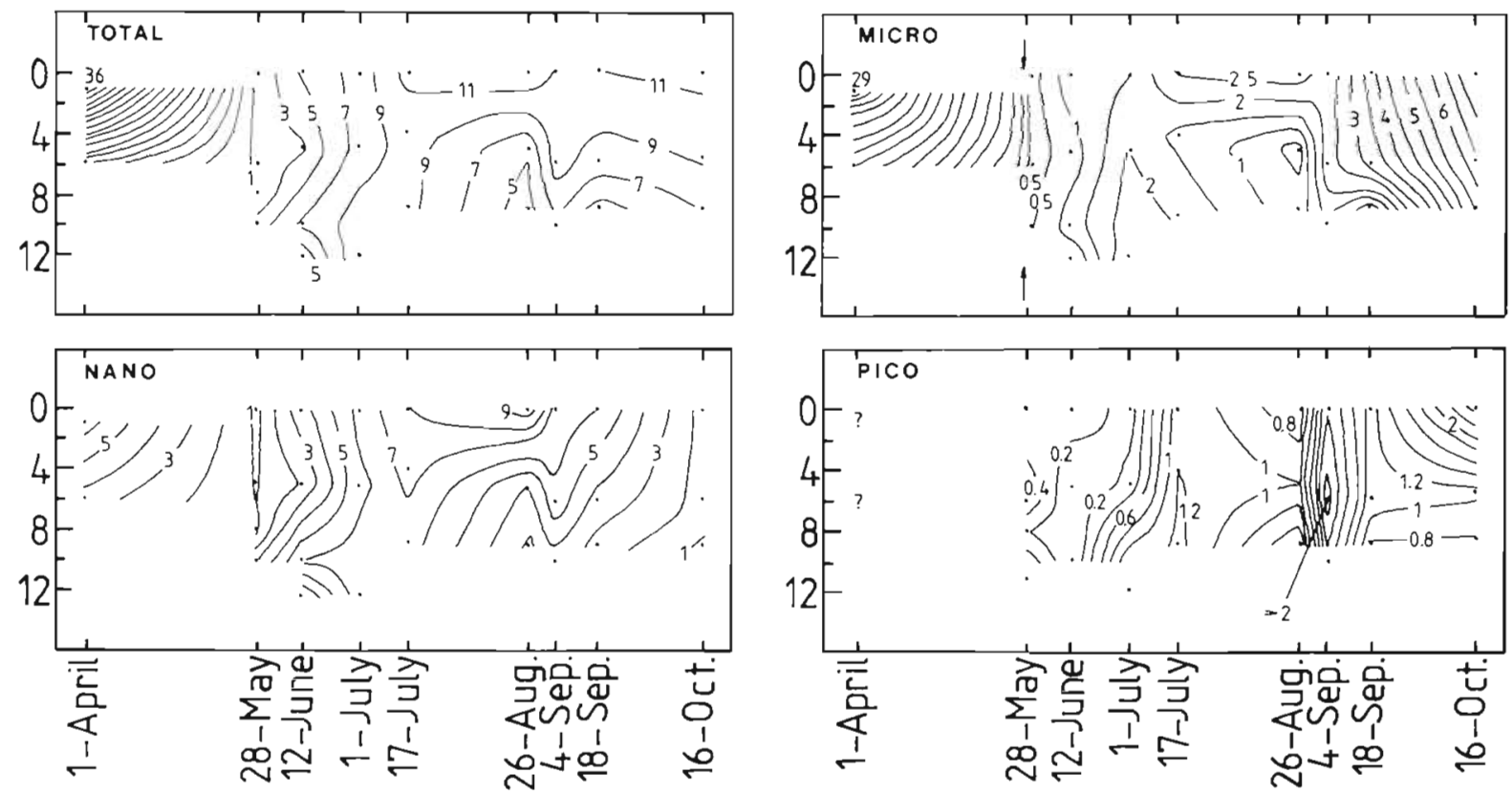
Whereas there was a decrease in total productivity from April to the end of May at the Bight stations (Stns $\mathrm{C}$ and D) productivity was fairly similar in April and May in Kiel Fjord (Stns A and B). In the fjord it increased to very high values in June and at Stn D there was a maximum in early July. Microscopic examination revealed Gymnodinium sp. (nano-sized) and Ceratium tripos (micro-sized) to have been the most abundant species $>3 \mu \mathrm{m}$ at Stn D in July. Common to all stations was the increase in total productivity from early September on, which was dominated by Prorocentrum minimum at Stn $\mathrm{A}$ and by microplanktonic dinoflagellates at the other stations. From May to the end of August nanoplankton was the most productive size fraction. Picoplankton reached its greatest importance in primary production on 1 July (21 to $39 \%$ )
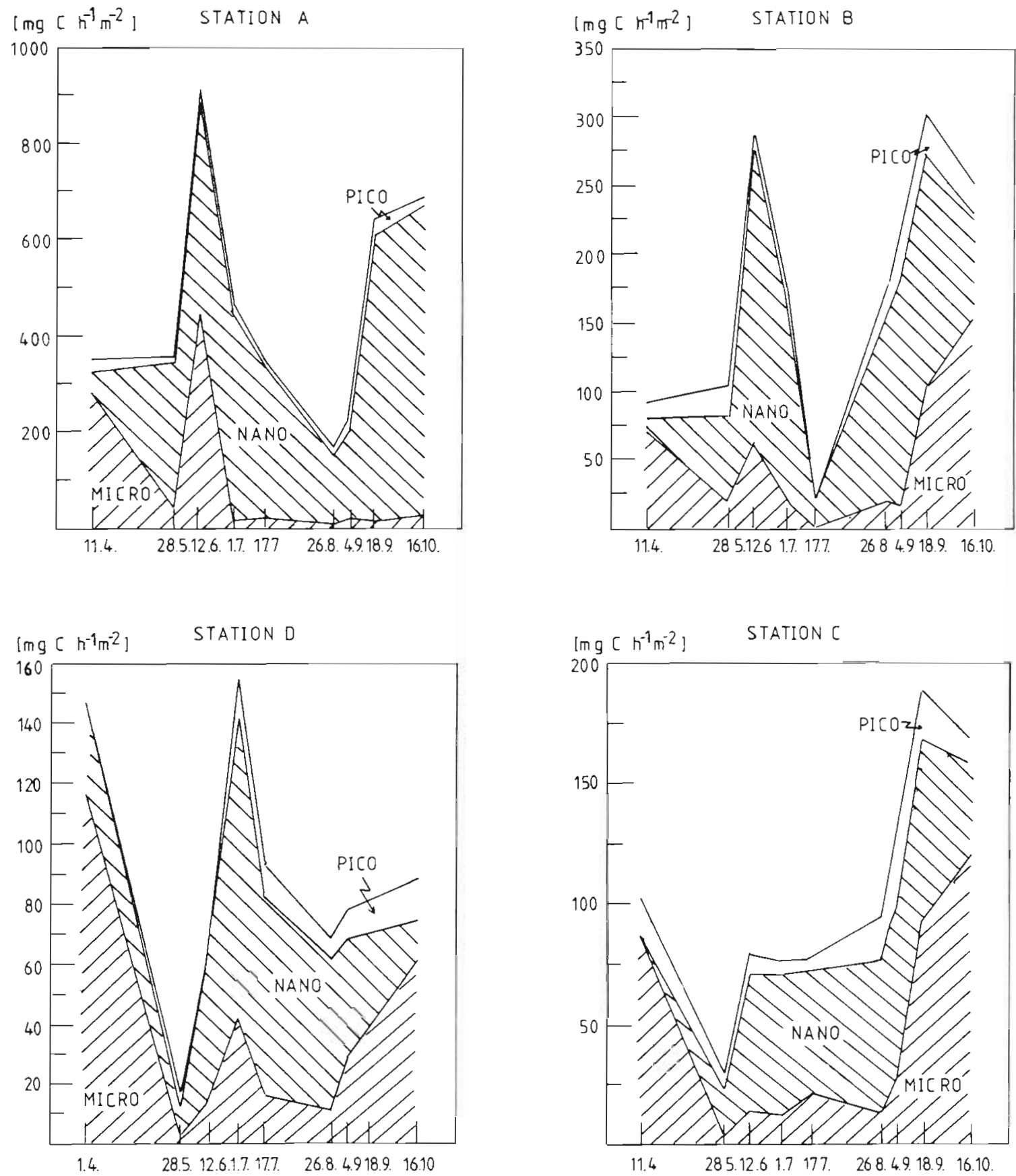

Fig. 9. Primary production integrated over the euphotic zone $\left[\mathrm{mg} \mathrm{C} \mathrm{m}^{-2} \mathrm{~h}^{-1}\right]$ at the 4 stations. Note different scales for each station 
and in early September (12 to $26 \%$ ) which, as for picoplankton chlorophyll, coincided with the population maxima of picocyanobacteria (Jochem 1988).

\section{DISCUSSION}

Size fractionation of natural plankton communities may cause serious difficulties and errors. High standing stocks may yield net or filter clogging so leading to an underestimation of the smaller size fractions. On the other hand long chains may disintegrate while screening. Experiments have shown that chains of Thalassiosira mostly disintegrate and behave according to their cell size rather than to their chain length (author's unpubl. data). In this case this might reflect their real ecological significance: if chains disintegrate so easily, one might expect a copepod to cut off single cells, too. Long cells might pass the screen by their long axes. Thus about $50 \%$ of Nitzschia closterium (up to $100 \mu \mathrm{m}$ in length) passed the $20 \mu \mathrm{m}$ gauze. Such cells, however, did not contribute much to phytoplankton standing stock during this study. If filters are used under weak pressure as in this work naked flagellates greater than the nominal pore size may pass the filter as a result of the plasticity of their cell wall. It is hardly possible to evaluate the actual impact of such effects on the measurements. Elser et al. (1986) suggest that the net effect might be negligible because of the contrary tendencies of the 2 effects.

The $3 \mu \mathrm{m}$ membrane filters used for size separation of picoplankton did not have straight pore canals like Nucleopore ${ }^{T M}$ filters. A comparison with $2 \mu \mathrm{m}$ Nucleopore $^{T M}$ filters done in the central Baltic in April/May 1986 revealed a significant underestimation of picoplankton with the filter in use here (Jochem 1987). Therefore the actual contribution of picoplankton to the phytoplankton community is likely to be underestimated in the data reported here.

\section{Vertical distribution of ultraplankton}

The growth season in Kiel Bight and Kiel Fjord showed 2 very pronounced nanoplankton biomass maxima: the one in May contributed by Dictyocha fibula and the other in August by Prorocentrum minimum. In inner Kiel Fjord the latter remained until the end of this study in mid-October. They both centred within or at the top of the pycnocline.

The results obtained during the bloom of Prorocentrum minimum, especially in inner Kiel Fjord, give some indications of pronounced vertical migration. Biomass (in terms of chlorophyll) strongly increased with depth for samples taken between 07:30 and 09:00 h. At local noon during the same period $P$. minimum concentrated within a thin layer at the surface (up to more

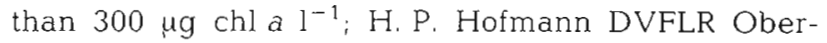
pfaffenhofen, FRG, pers comm.). In late August maximum primary production was found at the surface despite the biomass maximum having been at medium depths. Presumably, during night-time $P$. minimum gathers around the pycnocline to take up nutrients from the enriched bottom water. During daylight, they migrate to the surface where more light is available for photosynthesis. Similar vertical migration for this species is also reported by Tyler \& Seliger (1981) and Kimor et al. (1985). Edler \& Olsson (1985) reported similar diurnal vertical migration for Prorocentrum micans and Certium furca in the Kattegat area. Paasche et al. (1984) showed $P$. minimum to have the same uptake rates of nutrients in the light and dark. This vertical migration pattern would imply temporal separation of nutrient uptake and photosynthesis and might explain why the bottom water at Stn A was almost depleted of nutrients at the morning sampling time in September despite the inflow of nutrientenriched bottom water from Kiel Bight (more than $6 \mu \mathrm{mol} \mathrm{NH}_{4} 1^{-1}$ in the bottom water at Stn B) due to upwelling in inner Kiel Fjord. This depletion of nutrients might reflect the nutrient uptake by $P$. minimum during night-time. During daylight, the population concentrates at the surface, the bottom water is renewed due to upwelling that causes further inflow of bottom water from the Bight and new nutrients are provided for uptake during the next night. Furthermore, upwelling causes an outward advection of surface water in Kiel Fjord and so the population concentrated near the surface during daylight is transported towards the open Bight. After moving down at evening, the organisms can not only benefit from new nutrients but are also brought back to the inner fjord by the inflow of bottom water (Stienen 1986), so staying in a favorable environment. Although these ideas are based on indications rather than on hard data they fit well with the model given for this species in Chesapeake Bay by Tyler \& Seliger (1981). Diurnal studies may further clarify the life strategy and vertical migration patterns of this nanoflagellate.

The increasing productivity gradient with depth in September/October at Stn A was due to the enormous increase in biomass with depth at sampling time. The following in situ simulation incubation trapped the organisms in this 'morning depth'. This leads to the impression of a productivity maximum at greater depths which is however an artefact of methodology and does not reflect reality. Conchusions on vertical distribution should, therefore, always consider the sampling time, at least when dealing with motile species. 
In May, the depth of biomass maximum of the bloom of Dictyocha fibula clearly coincided with the depth of the pycnocline at all stations. Here, again, no productivity maximum occurred at the site of maximal biomass. Stienen (1986) reports a thin and dense layer of D. fibula at the surface at noon in May 1983 in Kiel Fjord. This may deduce the same pattern of vertical migration by this species as described for $P$. minimum.

In contrast to nanoplankton, picoplankton biomass maxima in May, July and September coincided with productivity maxima. In depth, they showed a relation to the pycno- and nutricline. Near the surface, a relation to higher nutrient concentrations was obvious. As already mentioned, the maximum in May has at least partly to be considered as disintegrated Dictyocha fibula. In July, the picoplankton chlorophyll maximum near the bottom could be regarded as related to the pycnocline as well, because in this case the pycnocline was lying on the bottom, and therefore not partitioning the water column. Further biomass maxima in April and August (due to allochthonous input of nitrate) paralleled productivity maxima.

Both nano- and picoplankton showed a clear relation to pycno- and nutriclines. During vertically mixed conditions, biomass was distributed more or less homogeneously and productivity decreased with depth due to decreasing light. Pycnoclines, however, seem to support both ultraplankton productivity and the structure of their vertical distribution. Such a relation to nutriclines was also described by Herbland et al. (1985) and Glover et al. $(1985,1986)$. This supports the classical view of high ultraplankton contributions in stratified and nutrient-depleted waters (Malone 1980, Smayda 1980, Parsons et al. 1984). If nutrient-rich bottom water is separated by a strong pycnocline, however, picoplankters seem to be unable to penetrate this pycnocline, perhaps because of their low Reynolds number that make it difficult for them to pass strong density gradients. So, high nutrient concentrations near the surface caused picoplankton maxima whereas the high nutrient concentrations near the bottom and beneath a strong pycnocline in June and September at Stns $B$ and $C$ did not lead to elevated picoplankton values. Vertical migration seems to be very limited for picoplankton whereas it seems to be an important life strategy for motile nanoplankton.

\section{Horizontal distribution of ultraplankton}

Generally higher nutrient concentrations in Kiel Fjord, due to allochthonous inputs from the city of Kiel and the River Schwentine, even during summer caused an overall increase in biomass and productivity towards the inner Kiel Fjord throughout the whole study period. Nanoplankton biomass and productivity and its contribution to the total phytoplankton community showed an increasing tendency towards Stn A. This was very pronounced during the bloom of Prorocentrum minimum in September/October. Picoplankton chlorophyll and productivity values were always highest at Stn A but the contribution of this size fraction to the total phytoplankton community increased towards the open bight.

These results are in good agreement with results cited in the literature. Throndsen (1978) reports an increasing ultraplankton productivity towards the inner Oslo Fjord; nanoplankton has a higher contribution in the inner and picoplankton in the outer Oslo Fjord. Larsson \& Hagström (1982) found lower picoplankton contribution at a eutrophicated station on the Swedish coast. McCarthy et al. (1974) report a lower contribution of the $<10 \mu \mathrm{m}$ size fraction near the runoff of eutrophicated rivers in Chesapeake Bay, USA.

\section{Seasonal importance of ultraplankton}

Spring phytoplankton mainly comprised the microplankton size fraction. Thereafter, ultraplankton dominated the phytoplankton community. After the nanoflagellate bloom in May (Dictyocha fibula), there was a typical 'summer community' from June to the end of August, displaying low biomass and productivity and a high contribution of ultraplankton of 70 to $100 \%$. This has also been reported from other coastal waters by various authors (McCarthy et al. 1974, Durbin et al. 1975, Throndsen 1978, Larsson \& Hagström 1982, Joint et al. 1986). Picoplankton reached its highest contribution of 8 to $30 \%$ of total primary production and chlorophyll in midsummer. This is in good agreement with the data of Joint et al. $(1986 ; 20$ to $30 \%$ in the Celtic Sea), Douglas $(1984 ; 13$ to $30 \%$ off Nova Scotia), Furnas (1983; 29 to $50 \%$ in Narragansett Bay), Kuparinen $(1987 ; \leq 50 \%$ off the Finnish coast), Larsson \& Hagström (1982; $40 \%$ on the Swedish coast), and Throndsen (1978; $\leq 90 \%$ in the Oslo Fjord). Based on Utermöhland autofluorescence-counts, picoplankton contribution during this time was 20 to $50 \%$ (Jochem 1988). The higher contribution on the basis of cell counts compared to chlorophyll and productivity measurements may be due to the underestimation of picoplankton in size fractionation by membrane filters as described above.

In April, there still were fairly high reserves of nitrate. This may indicate that the end of the foregoing spring bloom was due to the depletion of silicate or phosphate, the latter not measured for technical reasons. This is in contrast to Bodungen (1975) who found nitrate to be the limiting nutrient at the end of the spring bloom in Kiel Bight. In recent years, the ratio 
Table 2. Seasonal stages characterizing the growth season in Kiel Bight

\begin{tabular}{|llll|}
\hline Seasonal stage & Smetacek et al. (1984) & Dominating size fraction & Primary production \\
\hline Spring & I & Microplankton (Diatoms) & New \\
Late spring & II & Nanoplankton (Dictyocha) & 'New' \\
Summer & III & Nano- und picoplankton & Regenerated \\
Late summer & None & Nanoplankton (P. ninimum) & New' \\
Autumn & IV & Microplankton (dinoflagellates) & New \\
\hline
\end{tabular}

of nitrate to silicate seems to have changed to relavitely more nitrate, perhaps because of eutrophication, and silicate seems now to be the limiting nutrient for diatom growth in late spring (Bodungen 1986). The nitrate reserves were exhausted by the nanoflagellate Dictyocha fibula and seem to have maintained its bloom. Thereafter, ammonia was the main nitrogen source for primary production. As far as the inner Kiel Fjord is concerned, Stienen (1986) points out that due to allochthonous inputs of $\mathrm{NH}_{4}$, ammonia-consuming production might be considered 'new production' in this case.

The change from 'new' to ammonia-maintained, mainly regenerated production was characterized by a nanoflagellate bloom. Formerly, this was contributed by Prorocentrum balticum (syn. Exuviaella baltica; Lohmann 1908, Bodungen 1975, Smetacek 1975) but in recent years by Dictyocha fibula (syn. Distephanus speculum; Nöthig 1984, Neuer 1986, Stienen 1986, this study). This bloom exhausts nitrate reserves originating from the accumulated winter pool that have been left by the diatom spring populations (unpubl. nutrient data, Dept Marine Planktology, IfM, Kiel 1983-1985 and own data 1986) and freshly regenerated nitrate at the bottom (Bodungen 1986). In the eastern Baltic Kuparinen (1987) reports a nanoflagellate bloom during this time, too, that was dominated by Gonyaulax Catchata, Nannochloropsis sp., and Cryptomonas sp. Also, the bloom of the nanoflagellate P. minimum in the inner Kiel Fjord fell within a period of somewhat higher nitrate concentrations, and thus in the transition from 'regenerated' to 'new' production. Also in September, Furnas (1983) found blooms of $P$. minimum, P. triestinum, and Katodinium rotundatum in Narragansett Bay and Kuparinen (1987) reported K. rotundatum blooming off south Finland.

Based on sedimentation studies combined with numerous annual cycles of biological and hydrographic data, Smetacek et al. (1984) divided the growth season in Kiel Bight into 4 seasonal stages (Table 2). These seasonal stages are also reflected in the size structure of the phytoplankton community. Because of the above-mentioned nanoflagellate blooms that may take effect up to the open bight a further division of the stage 'summer' is recommended.
Except for short periods of the growth season that are characterized by the spring and autumn blooms, nanoplankton dominates the phytoplankton community in Kiel Bight. By their capability to undertake vertical migrations and to seek out depths of higher nutrient concentrations, nanoflagellates might have a significant ecological advantage in stratified waters. Picoplankton biomass and productivity also displays seasonal changes, and is not as constant as suggested by Malone (1980). Further studies and the use of adequate fractionation techniques may reveal a still higher contribution of this size fraction in Kiel Bight during summer. Nevertheless, results presented here show ultraplankton as a significant component of the phytoplankton community in this boreal inshore area, which can no longer be neglected in further studies. Similar results might be expected for other coastal and inshore areas as well as fjords.

Acknowledgements. This paper is part of a diploma thesis carried out under the supervision of Prof. Dr B. Zeitzschel and was partly supported by Stiftung Volkswagenwerk 'Wettbewerb Biowissenschaften'. I thank the crews of RV 'Alkor' and RV 'Littorina' as well as Mr Fritsche and Mr Werner for their assistance at sea and in the laboratory. I am grateful to Dr B. v. Bodungen, G. Behrends and R. Gradinger for critical reading and improvements of the manuscript.

\section{LITERATURE CITED}

Bodungen, B. v. (1975). Der Jahresgang der Nährsalze und der Primärproduktion des Planktons in der Kieler Bucht unter Berücksichtigung der Hydrographie. Dissertation, Kiel University

Bodungen, B. v. (1986). Annual cycles of nutrients in a shallow inshore area, Kiel Bight. - Variability and trends. Ophelia 26: $91-107$

Bröckel, K. v. (1981). The importance of nanoplankton within the pelagic antarctic ecosystem. Kieler Meeresforsch. Sonderh. 5: 61-67

Douglas, D. J. (1984). Microautoradiography-based enumeration of photosynthetic picoplankton with estimates of carbon-specific growth rates. Mar. Ecol. Prog. Ser. 14: $223-228$

Dugdale, R. C., Goering, J. J. (1967). Uptake of new and regenerated forms of nitrogen in primary productivity. Limnol. Oceanogr 12: 196-206 
Durbin, E. G., Krawiec, R. W., Smayda, T J. (1975). Seasonal studies on the relative importance of different size frac tions of phytoplankton in Narragansett Bay (USA). Mar Biol. 32: 271-287

Edler, L., Olsson, P. (1985). Observations on diel migration of Ceratium furca and Prorocentrum micans in a stratified bay on the Swedish west coast. In: Anderson, D. M. et al. (ed.) Toxic dinoflagellates. Elsevier Publ., New York, p. 195-200

Elser, J. J., Elser, M. M., Carpenter, S. R. (1986). Size fractionation of algal chlorophyll, carbon fixation and phosphatase activity: relationships with species-specific size distribution and zooplankton community structure. $J$. Plankton Res. 8: 365-383

Furnas, M. J. (1983). Community structure, biomass and productivity of size-fractionated summer phytoplankton populations in lower Narragansett Bay, Rhode Island. J Plankton Res. 5: 637-655

Glover, H. E., Campbell, L., Prézelin, B. B. (1986). Contribution of Synechococcus spp. to size-fractionad primary productivity in three water masses in the Northwest Atlantic Ocean. Mar. Biol. 91: 193-203

Glover, H. E., Smith, A. E., Shapiro, L. (1985). Diurnal variations in photosynthetic rates: comparison of ultraphytoplankton with larger phytoplankton size fractions. J. Plankton Res. 7: 519-537

Grasshoff, K., Ehrhardt, M., Kremling, K. (1983). Methods of seawater analysis, 2nd edn. Verlag Chemie, Weinheim

Herbland, A., LeBouteiller, A., Raimbault, P. (1985). Size structure of phytoplankton biomass in the Equatorial Atlantic Ocean. Deep Sea Res. 32: 819-836

Jeffrey, S. W., Humphrey, G. F. (1975). New spectrophotometric equations for determining chlorophylis $a, b, c_{1}, c_{2}$ in higher plants and phytoplankton. Biochem. Physiol. Pfl. 167: 191-194

Jochem, F. (1987). Zur Verbreitung und Bedeutung des autotrophen Ultraplanktons in der Kieler Bucht. Diploma thesis, Kiel University

Jochem, F. (1988). On the distribution and significance of picocyanobacteria in a boreal inshore area (Kiel Bight, Western Baltic). J. Plankton Res. 10: 1009-1022

Joint, I. R., Owens, N. J. P., Pomroy, A. J. (1986). Seasonal production of photosynthetic picoplankton and nanoplankton in the Celtic Sea. Mar. Ecol. Prog. Ser. 28 251-258

Kimor, B., Moigis, A. G., Dohms, V., Stienen, C. (1985). A case of mass occurrence of Prorocentrum minimum in the Kiel Fjord. Mar Ecol. Prog. Ser 27: 209-215

Kuparinen, J. (1987). Production and respiration of overall plankton and ultraplankton communities at the entrance of the Gulf of Finland in the Baltic Sea. Mar. Biol. 93: 591-607

Larsson, U., Hagström, \&. (1982). Fractionated phytoplankton primary production, exudate release and bacterial production in a Baltic eutrophication gradient. Mar. Biol. 67: 57-70

Legendre, L., Demers, S., Yentsch, C. M., Yentsch, C. S. (1983). The ${ }^{14} \mathrm{C}$ method: patterns of dark $\mathrm{CO}_{2}$ fixation and DCMU correction to replace the dark bottle. Limnol. Oceanogr. 28: 996-1003

Li, W. K. W., Subba Rao, D. V., Harrison, W. G., Smith, J. C., Culler, J. J., Irwin, B., Platt, T (1983). Autotrophic picoplankton in the tropic ocean. Science 219: 292-295

Lohmann, H. (1908). Untersuchung zur Feststellung des vollständigen Gehaltes des Meeres an Plankton. Wiss. Meeresunters. (Abt. Kiel) 10: 131-370
Lohmann, H. (1911). Über das Nannoplankton und die Zentrifugation kleinster Wasserproben zur Gewinnung desselben in lebendem Zustand. Int. Rev. ges. Hydrobiol. Hydrogr 4: $1-38$

Malone, T C. (1980). Algal size. In: Morris, I. (ed.) The physiological ecology of phytoplankton. Blackwell, Oxford, p. 433-463

McCarthy, J. J., Taylor, W. R., Loftus, M. E. (1974). Significance of nanoplankton in the Chesapeake Bay Estuary and problems associated with the measurement of nanoplankton productivity. Mar. Biol. 24: 7-16

Murphy, L. S., Haugen, E. M. (1985). The distribution and abundance of phototrophic ultraplankton in the North Atlantic. Limnol. Oceanogr. 30: 47-58

Neuer, S. (1986). Okologische Beobachtungen an sommerlichen Planktongemeinschaften in der Kieler Bucht. Diploma thesis, Kiel University

Nöthig, E.-M. (1984). Experimentelle Untersuchungen an natürlichen Planktonpopulationen unter besonderer Berücksichtigung heterotropher Organismen. Diploma thesis, Kiel University

Paasche, E., Bryceson, I., Tangen, K. (1984). Interspecific variation in dark nitrogen uptake by dinoflagellates. J. Phycol. 20: $394-401$

Parsons, T R., Takahashi, M., Hargrave, B. (1984). Biological oceanographic processes, 3rd edn. Pergamon Press, Oxford

Probyn, T. A., Painting, S. J. (1985). Nitrogen uptake by sizefractionated phytoplankton populations in Antarctic surface waters. Limnol. Oceanogr. 30: 1327-1331

Sieburth, J. McN., Smetacek, V., Lenz, J. (1978). Pelagic ecosystem structure: heterotrophic compartments of the plankton and their relationship to plankton size fractions. Limnol. Oceanogr. 23: 1256-1263

Smayda, T. J. (1980). Phytoplankton species succession. In: Morris, I. (ed.) The physiological ecology of phytoplankton. Blackwell, Oxford, p. 493-570

Smetacek, V (1975). Die Sukzession des Phytoplanktons in der westlichen Kieler Bucht. Dissertation, Kiel University

Smetacek, V. (1981). The annual cycle of protozooplankton in the Kiel Bight. Mar. Biol. 63: 1-11

Smetacek, V., Bodungen, B. v., Knoppers, B., Peinert, R., Pollehne, F., Stegmann, P., Zeitzschel, B. (1984). Seasonal stages characterizing the annual cycle of an inshore pelagic system. Rapp. P.-v. Réun. Cons. int. Explor Mer 183: $126-135$

Steemann Nielsen, E. (1952). The use of radioactive carbon $\left(\mathrm{C}^{14}\right)$ for measuring organic production in the sea. J. Cons. int. Explor. Mer. 18: 117-140

Stienen, C. (1986). Die Phytoplanktonentwicklung in Abhängigkeit von der Nährsalzkonzentration. Ber. Inst. MeeresKde Kiel 152

Strickland, J. H. D., Parsons, T R. (1972). A practical handbook of seawater analysis, 2nd edn. Bull. Fish. Res. Can. 167

Throndsen, J. (1978). Productivity and abundance of ultraand nanoplankton in Oslofjorden. Sarsia 63: 273-284

Tyler, M. A., Seliger, H. A. (1981). Selection for a red tide organism - physiological responses to the physical environment. Limnol. Oceanogr 26: 310-324

Valkenburg, S. D. v., Norris, R. E. (1970). The growth and morphology of the silicoflagellate Dictyocha fibula Ehrenberg in culture. J. Phycol. 6: 48-54

Manuscript first received: September 2, 1988

Revised version accepted: February 7, 1989 